\title{
Vera Tolz*
}

\section{Reconciling Ethnic Nationalism and Imperial Cosmopolitanism: The Lifeworlds of Tsyben Zhamtsarano (1880-1942)}

DOI 10.1515/asia-2015-1017

\begin{abstract}
This article intends to make a contribution to our understanding of how the Russian empire was shaped by its colonies by shifting the focus away from the circulation of knowledge between the European empires and onto crosscultural transfers between the imperial center and one part of Central Asia - the Buryat lands in southern Siberia and Outer Mongolia, during the first three decades of the twentieth century. The article looks at these transfers through the life of one remarkable individual, Tsyben Zhamtsarano, a Buryat from the Aga region on the eastern shores of the Siberian Lake Baikal. It argues that Zhamtsarano's case strikingly exemplifies a situation concerning the production of knowledge about the colonial periphery in which the colonized could have an upper hand, and their pre-eminence could be, at least partially, acknowledged in the imperial center. It is also demonstrated in the article how and why such an empowerment could only be temporary in Russia's ever changing imperial context.
\end{abstract}

Keywords: cultural transfers, empire, nationalism

The turn contemporary scholars have taken, away from focusing on discrete national traditions and towards studying entangled histories and cross-imperial transfers, as much as it has affected research on the Russian empire, tends to be overly Eurocentric. Transfers and dynamics of political and cultural entanglements are usually understood to be those between Russia and other European empires, who each learned something from the other about the techniques of controlling their colonial peripheries. ${ }^{1}$ In this interpretation contemporary scholars adopt the viewpoint of their subjects of study. In relation to Central Asia, for instance, various actors in late imperial Russia themselves drew parallels

1 See, for instance, Aust et al. 2010; Lieven 2000; Barkey/vonHagen 1997. The Eurocentric perspective is to an extent challenged in Burbank/Cooper 2010.

*Corresponding author: Vera Tolz, School of Arts, University of Manchester, Manchester, UK, E-mail: vera.tolz@manchester.ac.uk 
between their country's policies and British rule in India; Russian rule over the Caucasus was compared to French imperialism in Algeria. ${ }^{2}$ Some notable exceptions notwithstanding, we have too few systematic studies of the reciprocal impact that cross-cultural exchanges with the empire's non-European peripheries had on the Russian imperial core. ${ }^{3}$

This article intends to make a contribution to our understanding of how the Russian empire was shaped by its colonies by shifting the focus away from the circulation of knowledge between the European empires and onto cross-cultural transfers between the Russian imperial center and one part of Central Asia - the Buryat lands in southern Siberia and Outer Mongolia. The article's focus on the first three decades of the twentieth century will take us across the 1917 divide. It will look at these transfers through the life of one remarkable individual, Tsyben Zhamtsarano, a Buryat from the Aga district on the eastern shores of the Siberian Lake Baikal. Zhamtsarano was born in 1880, came of age at the turn of the twentieth century, becoming a major scholar, a leader of the Buryat national movement, a founder of the Mongolian People's Party, a tsarist and Soviet intelligence agent and eventually a victim of Stalin's purges. During his life he regularly moved between several parts of the world - Siberia, Outer Mongolia (one of the regions of the Chinese empire and then an independent state, the People's Republic of Mongolia) and the Russian/Soviet imperial center (St. Petersburg/Petrograd/Leningrad). He acted as an intermediary between these different worlds. Such multi-lingual, transcultural personalities from the empire's periphery entered Russia's cultural and political life in growing numbers at the turn of the twentieth century, leaving a particularly significant mark at the time of the 1905 and 1917 revolutions and in the 1920s. Among them Zhamtsarano was one of the most active. ${ }^{4}$

One has to be careful when drawing conclusions on the basis of remarkable individuals. At the same time, I would argue that the lives of such individuals present a productive subject for historians. Remarkable figures, such as the one discussed in this article, tend to appear on the scene at times of emerging new opportunities, which they are able to take advantage of. They complicate our understanding of the historical context in which they live and particularly well illuminate the processes of change which have taken place during their lifetime processes which otherwise might have remained hidden from our view as researchers.

2 Bobrovnikov 2010; Tolz 2010.

3 Khodorkovskii 2011; Khodorkovskii 1992; Khalid 1998; Kollmar-Paulenz 2014; Cooper/Stoler 1997. 4 Among the Buryats, other remarkable public figures of the period were Banzar Baradiin, Mikhail Bogdanov, Agvan Dorzhiev, Elbek-Dorzhi Rinchino and Gombozhab Tsybikov. 
The article's discussion of Zhamtsarano as a facilitator of political interaction and cultural transfer between the Russian empire and the Mongolian people allows us to look anew at three broader issues: (1) the relationship between what is commonly defined as "imperial cosmopolitanism" and "national particularism" at the time when nationalist movements on Europe's colonial peripheries began to challenge the imperial structures of the European states; (2) the agency of colonial subjects in the production of modern European knowledge about the colonial periphery and in the development of imperial policies more broadly; (3) the need to avoid essentializing the categories of the colonizer and the colonized and to appreciate instead a complex interplay between accommodation and resistance in a given imperial or colonial context.

In order to address these issues the article looks at Zhamtsarano as a nationbuilder among the Mongolian peoples of the Russian empire, who became known under the ethnonym Buryats; as a scholar of the Mongolian cultural tradition and of Buddhism; and as a representative of the Russian and Soviet imperial state in Outer Mongolia.

We have a fair amount of information about Zhamtsarano, including his scholarly publications, field diaries, private correspondence and passionate articles he wrote for the Russian and Mongolian-language press. We also have many pronouncements about him by different people, ranging from imperial scholars in St. Petersburg/Leningrad and fellow Buryat national activists to employees of the Mongolian government and Soviet secret police (OGPU and NKVD) officials. Many of his writings were in Russian, but he also wrote a significant amount in Mongolian and its Buryat variant, adapting the classical Mongolian script to the needs of the language spoken in his homeland. ${ }^{5}$ Significantly, in his personal diaries and notes, which he kept during his travels, he switched between Russian and Mongolian in a manner typical of an educated multi-lingual representative of the imperial borderlands at the turn of the twentieth century.

Confirming his position as an intermediary between different cultures, an important part of Zhamtsarano's literary heritage consists of translations of European literary and scientific works into Mongolian and of Mongolian epics, ritual texts and folklore into Russian. ${ }^{6}$ He simultaneously addressed multiple audiences, including various communities among the Mongols; residents of Siberia of different nationalities who read the local press in order to learn about political developments in their region; Russian imperial and Soviet

5 Dugarova-Montgomery 2008: 262-263.

6 "Bibliografiia rabot Ts. Zh. Zhamtsarano". In: Opisanie lichnogo arkhiva Ts. Zh. Zhamtsarano. Ulan-Ude: Izdatelstvo BNTs SORAN, 2010, 81-85. 
government officials; and Russian and European scholars. As far as his writings in Mongolian were concerned, they addressed, above all, the educated elites who could read the classical Mongolian script. But Zhamtsarano also hoped to engage this, at the time a relatively small, group of Mongols in his own farreaching enterprise of educating common people about what he understood to be their native cultural and historical tradition. In a symbolic reflection of his belonging to both Russia's imperial center and its periphery, his personal papers, which contain his multi-lingual correspondence with representatives of the Russian and Mongolian worlds, are split between state archives in the Buryat capital of Ulan Ude and St Petersburg. ${ }^{7}$

It is the contention of this article that Zhamtsarano (and there were some other Buryat activists $)^{8}$ played a central role in defining the key characteristics of the newly imagined Buryat nationality, which directly influenced how the Buryats started to be perceived by imperial experts in St. Petersburg and by the Bolshevik government in the 1920s. In fact, his case strikingly exemplifies a situation concerning the production of knowledge about the colonial periphery in which the colonized could have an upper hand, and their pre-eminence in the process could be, at least partially, acknowledged in the imperial center. This empowerment, however, yet again proved to be temporary.

An understanding of the peculiarities of the period in which Zhamtsarano lived is essential for making sense of his biography and his actions. It was the period of dramatic political, economic and social change. At the time of his birth, in 1880, the industrialization of Russia was intensifying, leading to rapid urbanization and population displacement. The period witnessed four revolutions - the first Russian revolution in 1905; two revolutions in 1917 and Stalin's so-called "Great Break" of the late 1920s-early 1930s, - as well as the First World War and the Russian Civil War. These processes and events were hugely traumatic for many, yet they also offered unexpected opportunities to those who had the ability to use them. It was a period of both discrimination and the unprecedented empowering of non-Russian minorities, including their increased access to education and, in the 1920s, to institutions of political power. Statesponsored and revolutionary terror paradoxically co-existed with certain liberalization in the aftermath of the 1905 and February 1917 revolutions and the weakness of state power in the 1920s. And so the first three decades of the

7 The Center of Oriental Manuscripts, the Institute of Mongolian, Buddhist and Tibetan Studies of the Siberian Branch of the Russian Academy of Sciences, Ulan Ude, fond 6; and the Archive of Orientalists, The Institute of Oriental Manuscripts of the Russian Academy of Sciences, St. Petersburg, fond 62.

8 See footnote 4. 
twentieth century offered individuals, influenced by the Russian intelligentsia's desire to achieve self-realization by serving a larger historical cause, unprecedented opportunities to perform this service through public activity, rather than merely through debates on the pages of literary journals or in narrow intelligentsia circles (kruzhki). With the advent of Stalinism these opportunities disappeared.

The dramatic political and social transformations of the 1900s-1920s were accompanied by cultural transformations which entailed a high degree of artistic and intellectual experimentation, and to which "marginal people" from the imperial peripheries significantly contributed. Their experiences of living in borderlands taught them from an early age how to make various cultural, and at times political, boundaries at least semi-permeable. These experiences taught them that whilst power relationships across these boundaries were always hierarchical, the hierarchies were nevertheless rarely firmly fixed. The crossing of cultural boundaries often created what Adam Weisberger called the "double ambivalence" of individuals or groups towards their own and other cultures, which inevitably provoked different responses. This ambivalence could be confronted with different strategies. While some "marginal people" chose assimilation or a zealous identification with their own culture and community, others preferred the strategy of transcendence, which entailed attempts to overcome "the opposition of the two cultures through creating a third way which is supposed to surpass them or reconcile them." 9 Those choosing such a strategy made the interaction between the center and the peripheries of the empire increasingly multi-directional, globalizing the world in which they lived. Zhamtsarano was one such individual.

\section{An account of Zhamtsarano's life}

Zhamtsarano was born into a family of a Buryat clan elder in Siberia's Transbaikal region (Zabaikale). ${ }^{10}$ The family was Buddhist but at the age of sixteen Tsyben was sent to study in the imperial capital in a gymnasium set up specifically for baptized Buryats. In 1897 he was expelled from that school for refusing to convert to Orthodox Christianity and returned to Siberia. Four years

9 Weisberger 1992: 429, 430.

10 This biographical account is based on the following sources: Ts. Zh. Zhamtsarano, “Avtobiografiia i spisok trudov", Tsentr vostochnykh rukopisei, Institut mongolovedeniya, buddologii i tibetologii Sibirskogo otdeleniya RAN (TsVRK IMBT SO RAN), fond 6, opis 1, delo 43, 1. 2a-b; Tsybikov/Chimitdorzhiev 1997; Reshetov 1998; Tsybikov 2003: 172-198. 
later he came back to St. Petersburg to study at the University. This proved to be a turning point in his life, which determined his future. At the University he met imperial Orientologists, the relationship with whom had a formative impact on his views. From then on a particularly important role in his life would be played by the two leading Russian specialists on Buddhism, Sergei Oldenburg and Fedor Shcherbatskoi, and a specialist on Siberia's ethnic minorities, Dmitrii Klements. $^{11}$

It is significant for our understanding of Zhamtsarano's position that the early twentieth century was a period that some scholars have called "the second Oriental Renaissance" in Europe, when the search for the origins of "European civilization" in the East acquired a new intensity, encouraging academics, artists and writers to come up with novel interpretations of the histories, cultures and religions of the "Orient". ${ }^{12}$ In this context, Buddhism held a particular fascination for the European elites. At the turn of the twentieth century Shcherbatskoi and Oldenburg came to the conclusion that academic studies of Buddhism in Russia could gain a significant advantage over Western scholarship in this field through involving in research representatives of Russia's Buddhist communities as interpreters of sources, rather than as mere collectors. This approach facilitated the creation of a new situation for some "natives", such as Siberia's Buryats, who began collaborating with imperial scholars in the production of modern knowledge about Russia's imperial domains. ${ }^{13}$

Eventually Zhamtsarano became a leading scholar in his own right, but prior to this, from around 1903, he also engaged in public activities. In 1905 he emerged as a founder and leader of the Buryat pro-autonomy movement. Despite the suspicion his political activities aroused on the part of the tsarist regime, in 1911 he was sent to Urga in Outer Mongolia (at the time a region of China) to promote the interests of the Russian empire there, at first glance a paradoxical decision. Clearly the choice of people whom the tsarist government could use for that purpose was extremely narrow at the time. ${ }^{14}$ This practice of relying on politically suspect individuals was common in late imperial and early Soviet Russia, in the instances when few alternatives were available. Alongside being an agent of the Russian empire in Mongolia, Zhamtsarano also pursued the aim with which he closely identified personally - the creation of a modernstyle school system for Mongolian youth, who had hitherto been educated either

11 Tolz 2011: 109-133.

12 Marchand 2009.

13 Tolz 2011: 117-118.

14 In 1911, the establishment of a Mongolian state was proclaimed, and Russia was keen to strengthen its influence over it. 
in monasteries, where emphasis was laid on education in Tibetan, rather than on Mongolian language proficiency, or in schools which trained clerks for the Banner administration. He also founded two newspapers, in which he published his own articles in Mongolian. ${ }^{15}$ Following the February 1917 Revolution Zhamtsarano returned to Russia, participated in the work of several Buryat congresses, was nominated as candidate for elections to the Constituent Assembly, joined the Socialist Revolutionary Party, and became one of the most vocal campaigners for national autonomy for the Buryats.

In 1920, he went back to Mongolia as an agent of the Comintern, and between 1921 and 1932 he occupied high positions in the Mongolian government. In 1920-1921, Zhamtsarano became a founding father of the Marxist-Leninist Mongolian People's Party, yet, at the same time, he was a leading member of the Buddhist reformist movement, which was active in both Buryatia and Mongolia from the early twentieth century until the late 1920s. In 1928 he was publicly condemned in Mongolia as a right-wing deviationist and propagandist of Buddhism. Upon his expulsion from that country in 1932 and until his arrest in 1937 on trumped-up charges of espionage for Japan he worked as a senior research fellow at the Institute of Oriental Studies of the Soviet Academy of Sciences in Leningrad. He died in a Soviet prison in $1942 .^{16}$

In effect, Zhamtsarano is a particularly striking example of an actor under conditions which can be described as an "imperial situation". ${ }^{17}$ The concept encourages scholars to move away from an essentialist understanding of empire, seen through the prism of binary oppositions. Instead, looking at specific “imperial situations" allows us to acknowledge that in an inevitably heterogeneous imperial context influences can flow not only from the dominant center, but also from the imperial or colonial periphery, and that it is often impossible for actors to belong unequivocally "to only one particular social hierarchy or group". ${ }^{18}$ We will now explore what Zhamtsarano's positions were and what impacts they had in imperial situations of the late tsarist and early Soviet periods. We will also see that Zhamtsarano's remarkable ability to cross boundaries and engage in multiple networks could have strikingly different effects from empowering to putting his very life in danger.

15 The newspaper Šine toli kemekü bičig (A Clear Mirror) was published in Urga 1913 and 1914. In 1915, Zhamtsarano initiated a new periodical Neislel küriye-yin sonin bičig (The Newspaper of the Capital Küriy-e), which ceased to appear when Zhamtsarano returned to Russia in 1917. Korostowetz 1926: 251.

16 Zhamtsarano was also accused of being a leader of an underground pan-Mongolian nationalist organisation.

17 This useful term was proposed by Gerasimov et al. 2005.

18 Glebov et al. 2013: 128-133. 


\section{Zhamtsarano as a Buryat nation-builder}

In the early twentieth century the Mongolian tribes around the Lake Baikal, by then commonly referred to in ethnographic literature and by imperial administrators as Buryats, were heterogeneous in terms of their customs, dialects and religious affiliations. Particularly pronounced were the differences between those living on the eastern shores of the Lake (Zabaikale) and its western shores in the Irkutsk region (Pribaikale). The distinctions in terms of customs and religious practices were to a significant extent a result of tsarist imperial policies. ${ }^{19}$ But in 1905, Zhamtsarano spoke about the "great liberation movement of the Buryat people" and in 1906 he proudly proclaimed that the Buryats were no longer a "narodnost" (an ethnic group without "national consciousness") but "nationalnost" (a community whose members were conscious of their common identity). ${ }^{20}$

The terminology and interpretative tools which he used reflected the European discourse of the nation. He talked about national unification, national consciousness and national revival, as well as the need for a community to have a commonly recognized and clearly defined "cultural heritage". The view that in order to become a modern national community a people should be aware and proud of their history and culture was shared by many European cultural figures of the time, including scholars who saw themselves as key agents in the collection and publicizing (in fact, constructing) of this heritage. ${ }^{21}$ At the turn of the twentieth century, some representatives of minorities in the eastern and southern borderlands of the Russian empire became actively involved in constructing the heritage of their own communities. Among the Buryats this process was particularly intense. Zhamtsarano quickly emerged as its leader, rather than a mere assistant of the actors from the imperial centre. ${ }^{22}$

For Zhamtsarano religious affiliation was not a reflection of an individual choice, but a collective identity of a group, defined through ethno-cultural markers. Significantly, this perception reflected both the official Russian imperial discourse of religion and the separately developed tendency among the

19 See, for instance, Pavlinskaya 2008; Montgomery 2005. In his travel diaries of 1903-1907 Zhamtsarano complained that Russian imperial administrators often applied the ethnonym "Buryats" to all the Mongol peoples who lived around Lake Baikal, rather than only to "real Buryats" (nastoyashchikh buryat) Zhamtsarano 2011: 26.

20 Zhamtsarano 1906: 184.

21 See, for instance, Hroch 1996.

22 Tolz 2009. 
peoples of Inner Asia to equate religious identity and community affiliation. ${ }^{23}$ Overall, Zhamtsarano's imaginings of the Buryat nationality, we can conclude, were articulated in the course of a "dialogue" with both - other representatives of the Buryat/Mongolian communities and imperial actors.

The beginning of the written record concerning Zhamtsarano's public activities, which is available to us, dates back to 1903 when Zhamtsarano, then a student at Petersburg University, went on a fieldwork trip to collect information on folklore and the religious practices of the local population in the Baikal region. During this and subsequent similar trips, he kept diaries, which shed an important light on his cultural identity. Most of the entries are in Russian. After all, his notes were to be turned into reports and articles aimed at the academic audience in St. Petersburg. However, some entries are written in Mongolian. While most such entries are recordings of Buryat folklore, some are of a personal nature. Particularly noteworthy seems the inclusion in the first diary of 1903 of Zhamtsarano's short autobiography, written in the classical Mongolian script. ${ }^{24}$ While visiting his native land as a representative of a European academic community with the purpose of producing imperial knowledge about Russia's non-European colonial domain, Zhamtsarano found it necessary to stress his belonging to and identification with the colonized. In his interaction with representatives of the Russian academic establishment he tended to adopt a dual position. On the one hand, he acknowledged his identity as a European scholar, talking in his letters to St. Petersburg academics about "our scientific world". At the same time, when describing developments among the Buryats, he always spoke as an insider, whose goal it was to make his imperial interlocutors adopt what he regarded as a "correct" understanding of the culture and traditions of the Mongolian people. ${ }^{25}$

From his letters, many of which were addressed to Oldenburg, and his diaries the following representation of the Buryats emerges: First, Zhamtsarano argued, the Buryat cultural tradition was formed under a strong influence of Tibetan Buddhism, and so he repeatedly described Buddhism as the Buryats' "native religion" and campaigned against the term Lamaism, which was commonly used by both imperial administrators and scholars in Europe and Russia, and which implied that Tibetan Buddhism was a corruption of the original

23 Werth 2000. I would like to thank an anonymous reviewer of this article for pointing out the similarity of the Russian imperial interpretation of religious affiliations and the approaches to this issue which were common among the peoples of Inner Asia.

24 TsVRK IMBT SO RAN, f. 6, op. 1, d. 23, No. 1, ll. 39b-41a.

25 Tolz 2013: 208. 
teaching of the Buddha. ${ }^{26}$ Speaking in the name of all the Buryats, he proclaimed in 1905: "We... support full freedom to study and practice our religion, according to the spirit and canon of Buddhism." ${ }^{27}$ Buddhism, he went on to argue, constituted the best "moral foundation" for the life of the Buryats. ${ }^{28}$ In this he conveyed to his interlocutors in the imperial capital a dominant view among the Mongolian elites with a Buddhist monastic education, according to whom only by adhering to Buddhism could the Mongols achieve enlightenment and overcome problems facing their communities.

He further insisted that Buddhism was fully compatible with European scholarship: "If we Buryats can obtain full freedom to profess Buddhism - we will solve in one stroke the issue of schooling and secular education in the native language. This is because all useful [European] sciences should be studied by Buddhists; this is our religious duty."29

In this period, other representatives of the emerging native intelligentsia with a national(ist) outlook also spoke about the compatibility of their religious traditions with European modernity. A well-known example were the Jadids, Russia's Muslim modernist reformers. ${ }^{30}$ What is significant with the case of Zhamtsarano, however, is that his interlocutors from among the St. Petersburg specialists in Buddhism began strongly to propagate the same view.

This idea of the compatibility and complementarity of Buddhist and European epistemology, as I have argued elsewhere, informed the approach to the study of Buddhism which was developed in St. Petersburg-Leningrad during the first three decades of the twentieth century through a dialogue between Shcherbatskoi and Oldenburg, on the one hand, and, on the other, Zhamtsarano and several other Buryats, who came to St. Petersburg as students in the first years of the twentieth century, after undertaking traditional Buddhist education. ${ }^{31}$

In contrast, the worshiping of Shamanic deities, which, in fact, was widespread among the Buryats, provoked harsh criticism from Zhamtsarano. In his

26 TsVRK IMBT SO RAN, f. 6, op. 1, d. 16, 1l. 1a-2b: Zhamtsarano’s letter to Russian Prime Minister Sergei Witte of 7 February 1905 about the needs of Buryat Buddhists, and f. 6, op. 1, d. 16, 1l. 3a-4b, "Reshenie sezda zabaikalskikh buryat po voprosam svobody veroispovedaniya, 26-29 aprelya 1905 g.," which, among other things, demanded that the Russian authorities should stop "labelling the Buddhist religion [of the Buryats] Lamaism".

27 The St. Petersburg Branch of the Archives of the Russian Academy of Sciences (PF ARAN), f. 208, op. 3, d. 210, 1l. 16-18.

28 PF ARAN, f. 208, op. 3, d. 210, 1. 4.

29 PF ARAN, f. 208, op. 3, d. 210, 1. 18.

30 Khalid 1997: 191, 200.

31 Tolz 2011: 101-110. 
view, Shamanism lacked any morals and only "led to alcoholism" among the Buryats. In turn, he depicted conversion to Orthodox Christianity as nothing but "artificial". 32 In his depiction of those Buryats who were not Buddhists, Zhamtsarano systematically drew on the Mongolian Buddhist discourse, reflected, for instance, in Mongolian historical chronicles, on which he eventually became a world renowned expert. ${ }^{33}$ In line with the representational technique of these chronicles, he depicted the areas populated by nonBuddhist Buryats as a "region of darkness", where, he hoped, the "sun of the dharma" 34 would eventually shine. ${ }^{35}$

The second component of Zhamtsarano's national imagining was the view that the Buryats needed a common literary language and that Buryat literacy should be based on the old Mongolian script. In the first decade of the twentieth century, Zhamtsarano was personally involved in the development of such a script, strongly opposing proposals to adapt the Cyrillic alphabet to the needs of the Mongolian/Buryat language. ${ }^{36}$

The third essential element of his perception of the Buryat cultural tradition was the clan system (rodovoi stroi), which was supported by the tsarist legislation of 1822, but threatened by the administrative reform of 1900-1901. Criticizing this reform as highly damaging for the Buryats, Zhamtsarano stated in his letter to Oldenburg of 1903 that the clan system was "the basis of the moral order" among the Buryats and acted as their "protector from negative influences." 37 "There were instances when taishas [leaders of the Buryat clans] abused their power, but these were isolated cases and they did not happen everywhere," he went on to explain. "In any event, they [taishas] cared about the well-being of the Buryats, striving to maintain a good standing among their fellow tribesmen...." "All [the Buryats] say with one voice that when the local Dumas, taishas and shulegas [also a Buryat clan leader] existed, Buryats did

32 PF ARAN, f. 208, op. 3, d. 210, ll. 6-6ob.

33 Zhamtsarano's book on the seventeenth-century Mongolian chronicles (Zhamtsarano 1936) is still regarded in Mongolian Studies as the standard work.

34 Dharma is one of key concept in Buddhism.

35 See, for instance, Zhamtsarano 1909: 393-394. For examples of such a discourse in Mongolian chronicles, see, for instance, Sayang Sečen, Erdeni-yin Tobči (folio 76v29-77r5), published in Haenisch 1955. This discourse first appeared in the chronicles in the seventeenth century and continued up to the twentieth century. I am grateful to Karénina Kollmar-Paulenz for providing me with this information and reference.

36 Dugarova-Montgomery 2008: 262-263.

37 PF ARAN, f. 208, op. 3, d. 210, 1l. 4ob and 6. Zhamtsarano 2011:19. 
better economically and morally...," he insisted. ${ }^{38}$ He further developed this view in his articles for Siberia's Russian-language press. ${ }^{39}$

Problems among the Buryats, such as venereal disease and alcoholism, were not the result of the "low developmental level" of the Buryats, as Russian imperial administrators and the press claimed, but were the fault of Russian settlers in Siberia. "The Russian influence is on the whole negative. The Russian element... is corrupted", he argued in a letter to Oldenburg, simultaneously making similar statements in his fieldwork diaries. ${ }^{40}$

Finally, Zhamtsarano's imagining of the Buryat nationality was not spatially constrained by the borders of the Russian empire. For him, the Transbaikal Buryats were the "vanguard" of the Mongolian people, including not only the Buryats on both sides of Lake Baikal, but also the population of Outer Mongolia. He believed that the Buryats/and the Mongolian people were a community-inthe-making. ${ }^{41}$ His writings betray a sense of a personal mission as the creator of such community. In a newspaper article of 1906 he grandly described his goal as "the unification of all the groups of the Buryat population in the Transbaikal region and the Irkutsk gubernia... also developing their legal consciousness". ${ }^{42}$ In his interactions with the imperial authorities he was a political realist and understood that he could be most successful if he aligned his personal goals with those of Russia's rulers, hence his argument that the Buryats could play an important role as transmitters of Russian/European influences in Asia. ${ }^{43}$

The problem was that few fellow Buryats shared Zhamtsarano's vision when he first started expressing it in the first years of the twentieth century. Buddhism and literacy in Mongolian could be spread more easily among the Transbaikal Buryats, of whom Zhamtsarano was a representative. ${ }^{44}$ Among the Irkutsk Buryats, in contrast, the worshiping of shamanic deities was common, as were conversions to Christianity - the result of the efforts of Orthodox missionaries in the region. The literacy that existed among the Buryats of Pribaikale was mostly in Russian.

From 1905 onwards, Zhamtsarano spent a lot of time among the Irkutsk Buryats propagating his vision of the Buddhist Buryat nationality, whose

38 PF ARAN, f. 208, op. 3, d. 210, 11. 4ob and 6.

39 See, for instance, Zhamtsarano 1907: 6-7.

40 PF ARAN, f. 208, op. 3, d. 210, 1l. 2ob-4ob.

41 Quoted in Tsybikov 2003: 185.

42 Zhamtsarano 1906: 170.

43 Rupen 1956: 385, 388, 390-393.

44 The levels of literacy among the Buryats when Zhamtsarano began his political activities were low. Even in Transbaikale's Aga district, where Zhamtsarano was born, of 39,000 people only 13\% were literate in either Mongolian or Tibetan and 1\% in Russian. See Atwood 2004: 160. 
cultural tradition included literacy in classical Mongolian. His position and actions were resented by Irkutsk Buryat activists who proposed a different vision of their community, in which religion was relegated to the private sphere, literacy was to be based on the Latin or the Cyrillic script and the main political goal was the achieving of a better representation of the Buryats in the newly created Russian State Duma, rather than the preservation of the clan system. ${ }^{45}$

Zhamtsarano's activities were also criticized by conservative representatives of the Russian imperial establishment, who detected a separatist threat in his position, ${ }^{46}$ but liberals in St. Petersburg applauded it, ensuring that the liberal Russian press depicted the developments among the Buryats and their aspirations for the future during the 1905 revolution and its aftermath in accordance with Zhamtsarano's views.

In the newspaper Syn Otechestva, Oldenburg repeated Zhamtsarano's representation of Buddhism as a "native religion of [all] the Buryats" and literacy in classical Mongolian as native to the community. ${ }^{47}$ Oldenburg was also persuaded by Zhamtsarano's criticism of the term "Lamaism” and he began criticizing the usage of the term by European scholars of Buddhism. ${ }^{48}$ In turn, in 1907 and 1908, Klements published several influential articles, in which he came out in defense of the Buryat clan system as the "moral foundation" of their way of life. He referred to Zhamtsarano as the main source of his knowledge about the Buryats, unequivocally endorsed his position and dismissed Zhamtsarano's main Irkutsk opponent as an ignorant charlatan. ${ }^{49}$

In 1910, another Petersburg ethnographer, Lev Shternberg, published two essays about the developments among Siberia's minorities during the 1905 revolution. He paid special attention to the Buryats, among whom, he noted, the appearance of a politically conscious intelligentsia was particularly rapid. Shternberg acknowledged that politically active Buryats were divided in their understanding of what best served the interests of the "Buryat nationality". Without giving any evidence, Shternberg claimed that "the Buryat intelligentsia and ordinary people" (even in Pribaikale) offered Zhamtsarano their "passionate

45 Bogdanov 1907.

46 A.M. Pozdneev, "Otchet o poezdke k terskim, uralskim i orenburgskim kalmykam", Arkhiv vostokovedov, Institut vostochnykh rukopisei RAN (AV IVR RAN), f. 44, op. 1, d. 60, 1. 97; and Pozdneev, "O novom buryat-mongolskom alfavite", AV IVR RAN, f. 44, op. 1, d. 69, ll. 1-5.

47 PF ARAN, f. 208, op. 3, d. 28, 1. 23; PF ARAN, f. 208, op. 3, d. 210, 11.16 and 18; f. 208, op. 3, d. $196,11.18-19$.

48 Tolz 2011: 128, 141.

49 Klements 1907 and 1908. 
support”, and he repeated Zhamtsarano's accusation that his opponents were tsarist police informants. ${ }^{50}$

So we can see that the dominant image of the "Buryat nationality" crystallizes at the time of the 1905 revolution on the basis of one particular position, to a large extent developed by Transbaikal Buryats. Zhamtsarano (and several other Buryats with a background similar to his) borrowed the European concept of Kulturnation, using it as a tool to represent the Buryats according to their own ideals and practical goals. Significantly, Zhamtsarano linked the national idea with the Mongolian elites' discourses about the centrality of Buddhism to the Buryat/Mongolian identity and with their demonization of Shamanism.

Zhamtsarano's imagining of the Buryat nationality was then brought by its inventor to the Russian capital to be publicized there by politically engaged imperial scholars through the liberal press. The reason that Zhamtsarano's vision, rather than that of his Irkutsk opponents, came to dominate had a lot to do with the fact that Zhamtsarano had stronger personal ties with members of the intellectual elite in St. Petersburg. The latter also preferred his vision because it emphasized the importance of "cultural and historical heritage", rather than contemporary realities on the ground, for imagining particular people as a nation. This is precisely how Oldenburg and other supporters of Zhamtsarano in St. Petersburg understood what a national community was supposed to be, i.e. a community bound by culture, religion and shared history. ${ }^{51}$ There is little reflection in the dialogue between Zhamtsarano and his imperial interlocutors on how they themselves became instrumental in constructing this "cultural and historical heritage" and the extent to which this "heritage" was also a result of Russian imperial policies. Instead, they believed that the vision they promoted was a product of long-term grass-root indigenous developments.

The role of these imaginings in whose production Zhamtsarano played such an important role only increased in the first decade post-1917. In this period, according to a fellow Transbaikal Buryat activist, Banzar Baradiin, Zhamtsarano worked tirelessly to secure the autonomy of the Buryats, and to ensure that it was not undermined during the imposition of Soviet rule in the region. ${ }^{52}$

In 1923, at the time of the creation of the Buryat-Mongol autonomous republic within Soviet Russia, most of its newly appointed leaders (all Transbaikal Buryats) viewed Buddhism as their "national religion”, positively assessed the role of the datsans and regarded lamas as part of Buryatia's nascent

50 Shternberg 1910: 605, 606, 622, 623. Compare Zhamtsarano 1907.

51 Tolz 2011: 122.

52 Quoted in Reshetov 1998: 19. 
intelligentsia. ${ }^{53}$ The Buryat literary language was to be based on the Khalkha dialect of Mongolian, as Zhamtsarano had advocated. ${ }^{54}$ According to the analysis of the situation of the east Siberian "natives" produced in 1923 for the local branch of the Russian Geographical Society, by an author from Buryatia, current perceptions of the Buryat nation were fully in line with what the Zhamtsaranoled group had been arguing since the first decade of the twentieth century. ${ }^{55}$ The report maintained that the prejudice that the "natives" were "permanently in a state of mental and moral dormancy" had already been destroyed in the late imperial period through the joint efforts of imperial scholars and their local associates such as Zhamtsarano. ${ }^{56}$ In line with the perceptions articulated in the late imperial period by Zhamtsarano and his supporters from among the liberal St. Petersburg intellectuals, the author described the "natives" (tuzemtsy) of Siberia as "superior and more cultured than the Russian [settlers]" in "their methods of child rearing... their attitude to women, [and] their relationship with their neighbors," ${ }^{57}$ i.e., in relation to the key parameters according to which the levels of civility of a particular community were measured in ethnographic studies.

In the 1920s, ideologically the most powerful movement among the Buryats was the Buddhist renewal movement. The movement advocated reforming and modernizing Buddhism along the lines which Buryats such as Zhamtsarano had first started outlining during the 1905 revolution. ${ }^{58}$ This involved the restructuring of the monastic administration, especially the elimination of what the reformers saw as the excess wealth of the monasteries and a stricter adherence to the monastic vows, which were very lax. Zhamtsarano, in particular, also campaigned for the introduction of a more general education system at datsans. ${ }^{59}$ The history of the movement is that of a multi-directional interaction between the various groups of "traditionalists" and "modernizers" among the

53 Kozmin 1923.

54 Otchet IV Plenuma Vses. Tsent. Kom. Novogo Alfavita proiskhodivshego v gorode Alma-Ata, s. 1., 1931, 34-35. Montgomery 2005: 238-253.

55 Kozmin 1923: 84-87.

56 Kozmin 1923: 73.

57 Kozmin 1923: 74.

58 The Buddhist renewal movement received an important boost during the work of the Provisional Government's Commission on Revising the Legislation on Buddhists of Russia. The Provisional Government's Commission suggested that the term Lamaism stopped being used in Russian legislation on religious matters. However, the term was "rehabilitated" in the Soviet period and is utilized by some Russian scholars even today, whereas most Western Buddhologists now accept its problematic nature. See Gerasimova 1964: 24-26.

59 Gerasimova 1964. 
Buryats, imperial scholars in St. Petersburg and, in the 1920s, the Soviet authorities as well. The ideology of the movement was further influenced by the contemporary renewal movement (obnovlencheskoe dvizhenie) in the Russian Orthodox Church and reformist trends in Japanese Buddhism. ${ }^{60}$ In their battle against the "traditionalists" Zhamtsarano and other Buryat reformers insisted that Buddhism was compatible with European thought - an idea that was shared by the St. Petersburg imperial scholars. At the time of the first Spiritual Congress of Buddhists, in 1922, the claim of Buddhism's compatibility with communism and Marxism was added, thus helping to create a situation which retrospectively seems paradoxical. ${ }^{61}$ In the 1920s, the atheistic Communist regime gave Buddhists in the Soviet Union a greater opportunity to profess their religion than had been the case in the late tsarist period. ${ }^{62}$

Zhamtsarano's activities were not limited to imposing his vision on Irkutsk Buryats. He also saw Buryats as part of a larger community of the Mongolian people, including those who lived outside the borders of the Russian empire. Here his vision temporarily interlinked with the goals of the tsarist and Soviet governments. From 1911 he was a tsarist, and from 1920 a Soviet, agent, yet this definition does not sum up all aspects of his activities. As we can see, he was a self-aware nation-builder, for whom the promotion of the Buryat cause, as he understood it, was of the upmost importance. ${ }^{63}$

So, Zhamtsarano's work for the tsarist government in Outer Mongolia between 1911 and 1917 and then for Comintern and the Soviet government between 1920 and 1932, including conducting intelligence work under the name of Tsyben Begzeev, cannot be dismissed either as the actions of a representative of the colonial periphery with little opportunity to make his own choices or as an example of mere political opportunism. His writings continued to reflect his self-perception as a person with a mission. The mission, in his own words, was that of ensuring that Transbaikal Buryats remained the "avant-garde of the Mongols", never slipping into the position of a "rearguard". ${ }^{64}$ His belief that the Buryats should act as transmitters of European values in Asia, which he had already stated in the first decade of the twentieth century, was, in the 1920s, temporarily appropriated by the leadership of the Soviet Commissariat of

60 Sharf 1993; Rozenberg 1918.

61 "Protokoly zasedaniia pervogo Vsesoiuznogo dukhovnogo sobora buddistov SSSR", AV IVR RAN, razryad II, op. 1, d. 373, 1l. 2-3, 24-25; "Protokoly 3-ego Buddiiskogo dukhovnogo soveta Buriatii”, AV IVR RAN, razryad II, op. 1, d. 373, 1l. 29-30. (These protocols of two different meetings are kept in the same archival file.)

62 Andreev 2004.

63 Kallinikov 1928; Bazarov 2008: 38, 40.

64 Quoted in Tsybikov 2003: 185. 
Foreign Affairs. ${ }^{65}$ So, when Zhamtsarano was establishing a modern school system and a Learned Committee on the Russian model in Outer Mongolia and when he was authoring the political platform of the People's Party of Mongolia in 1921, he was realizing not only the goals of the Soviet regime but also his own hopes and ideals. First, his goal was to expose the Mongolian people to European modernity, as his articles about European culture and thought in the Mongolian press and his translations of European literature into Mongolian suggest. A no lesser, if not more important, goal was to educate Mongols about their own culture and history. When collecting virtually every example of the Mongolian cultural tradition he came across, Zhamtsarano aimed to make them available not just to a few Russian and European scholars, but to the Mongolian people as well. His editions of numerous Mongolian epic, ritual and folkloric texts, as well as his articles in the Mongolian language on issues ranging from archaeological findings in Buryatia and Mongolia to the geography of the lands populated by the Mongols point to this. ${ }^{66}$ Finally, he kept promoting Buddhism as the foundation of the Mongolian culture and way of life. It is significant for our understanding of Zhamtsarano that, from 1928 onwards, he continued to defend his views even after Moscow's policies of toleration of Buddhism had turned into a vicious anti-religious campaign. He even continued to uphold his understanding of Buddhism as a central component of the identity of the Mongols during his NKVD interrogations upon his arrest in 1937. Justifying his rejection of the Soviet government's campaign against Buddhism he argued: "I regarded as counter-revolutionary and a provocation the decision to eliminate monasteries and lamas..." 67

Zhamtsarano's downfall as a politician in the late 1920s was not only a result of the fact that his vision of the Buryat nation and of the Mongols as a cultural community became incompatible with the agenda of the Soviet government and his regular trans-border travels made him politically suspect at the time when the Soviet regime was becoming increasingly isolationist. Zhamtsarano's additional problem was that some members of the government of the People's Republic of Mongolia were only too happy to see him removed from a leadership position in Ulan Bator, because in their view he was not a fellow Mongol national leader, but a colonizer, who was representing a foreign imperial power. His case thus complicates our ability to draw a boundary

65 Andreev 2004: 96-99 notes a particularly important role of Agvan Dorzhiev, a Transbaikal Buryat who was an adviser to the Dalai Lama, in promoting a special role that Buryats could play in Soviet foreign policy.

66 "Bibliograpfiia rabot Ts. Zh. Zhamtsarano". In: Opisanie lichnogo arkhiva Ts. Zh. Zhamtsarano. 67 Quoted in Reshetov 1998: 40. 
between the colonizers and the colonized, and also highlights the ambiguity in the relationship between the promotion of imperial policies and resistance to them.

\section{Zhamtsarano's orientalist perceptions}

Throughout his life, Zhamtsarano was not infrequently reminded of his position as a colonial subject. The externally imposed inorodets (alien) identity limited his rights. In 1897, his refusal to convert to Christianity led to his expulsion from an elite school. In 1904, when St. Petersburg University asked the Chita district police to issue Zhamtsarano with an open-ended (bessrochnyi) passport, so he could travel across the empire to do academic fieldwork without any restrictions, the request was denied. He was reminded that, being an inorodets, he was "not entitled to possess the document which was given only to members of the privileged estates". ${ }^{68}$ Unsurprisingly, his writings are permeated with complaints about the exploitation of the Buryats by Russian imperial administrators. As he put it in one of his letters to Oldenburg: "If the government has the goal of the well-being of the Buryats, then by abolishing the [steppe] Duma and the institute of taishas it has achieved results that are the opposite to those desired. But if its goal has been the weakening and the annihilation of the Buryats, then it is achieving great results." 69

At the same time, however, some of Zhamtsarano's actions could be viewed as those of a colonizer and he used a distinctly Orientalizing language in talking about those communities which were the target of his "civilizing mission", particularly the Irkutsk Buryats and the population of Outer Mongolia. For Zhamtsarano these communities were not the external Other, but a backward part of the self, which had to be enlightened in order to be able to partake in a historical cause. As with his other visions, he began to disseminate such perceptions in his interaction with interlocutors from among the imperial elites as early as during the first decade of the twentieth century. Significantly, Zhamtsarano's orientalizing stance towards the communities of his fellow Mongols came largely not from his appropriation of discourses of imperial actors, but from his sharing dominant views of the Buryat/Mongolian elites with the Buddhist monastic education.

68 Rossiiskii gosudarstvennyi istoricheskii arkhiv (RGIA), f. 14, op. 15, d. 520, 1. 10.

69 See, for instance, PF ARAN, f. 208, op. 3, d. 210, 11. 2ob, 3ob and 4; Zhamtsarano 2011: 11-12, 14, 19, 21, 22. 
Using standard tropes of the Mongolian historical chronicles condemning non-Buddhist Mongols and particularly the "ignorance" and "crudeness" of shamans, Zhamtsarano thus wrote in 1909: "The region is engulfed in darkness; this ignorance, this hellishness is perpetuated... by adverse conditions... It cannot be ruled out that the Buryats will continue curing their sick through bloody sacrifices,... [and] shamanic rituals... for years to come."70 What could change all this was mass schooling in the native language, using the script which Zhamtsarano was at the time designing. Tellingly, while rejecting shamanic approaches to dealing with illness, Zhamtsarano praised Tibetan healing methods, on which Trainsbaikal Buryats often relied, and criticized European doctors for failing to appreciate the value of Tibetan medicine. ${ }^{71}$

Here again we see similarities and differences between Zhamtsarano and other nationally-minded intellectuals from among Russia's minorities. Jadids in Central Asia were also concerned with what they perceived as the backward customs of their society. The answer from their point of view was learning from the Europeans, particularly in areas such as medicine and public hygiene. Zhamtsarano's position seems more complicated. His model for all the Mongolian people was not just that of European modernity. In fact, one group of the Mongols, the Transbaikal Buryats, who were Buddhists, in his view, also possessed its own "indigenous" knowledge and practices which could help all the Mongols transform their societies in order to meet the challenges of the modern world.

As noted above, Zhamtsarano's depictions were taken at face value by Oldenburg, Klements and Shternberg - the main commentators on Buryat affairs in St. Petersburg. Under such circumstances, the objections of Zhamtsarano's opponents had little chance of being heard in the imperial capital.

The population of Outer Mongolia, including the local elites, were similarly denigrated by Zhamtsarano. In his description, Outer Mongolia was stuck in the "Middle Ages", and was "politically and culturally immature". ${ }^{72}$ We find exactly the same statements in the Soviet OGPU reports about Mongolia, such as one dated 1924 which argued that: "The Buryats... stand at a politically higher level than the analogous officials who are Mongols; they [Buryats] are better educated and they are transmitters of ideas and cultural principles, which are new for Mongolia...”73

70 Zhamtsarano 1909: 393-394. See also PF ARAN, f. 208, op. 3, d. 210, 1l. 4, 6-6ob.

71 Zhamtsarano 2011: 12.

72 Quoted in Reshetov 1998: 40.

73 The text of the OGPU report is published in Bazarov/Zhabaeva 2008: 319-329 (the quote is on p. 326). 
In this context, the appearance of an anti-Buryat proclamation in Urga (future Ulan-Bator) at the time of the creation of the Mongolian People's Republic in 1924, which was signed by 49 members of the Mongolian government and posted around the city, does not look surprising. Reflecting a strong animosity among the Mongolian political elites towards the presence of Soviet Buryats in their midst, the proclamation, which mentioned Zhamtsarano by name, stated that the Buryats, together with their "Red Russian masters", only pretended to work for the common good of the Mongolian people and to support Buddhism. Zhamtsarano and three other Buryats in the Mongolian government were called "gluttonous dogs" who wanted to embezzle government money, eventually escaping back to the Soviet Union with their loot. ${ }^{74}$

The issue of the boundary between the colonizers and the colonized is closely linked with the issue of agency. In the Russian and early Soviet imperial space (and likely other imperial spaces too) the agency of those subjected to European imperialism was reflected not only in their acts of resistance, but at times also in the instances of their close involvement in imperial and colonial policies. ${ }^{75}$ As nationalism and imperialism did not necessary directly oppose one another, resistance to and partaking in imperial/colonial rule could also go hand in hand. This is what we see in the case of Zhamtsarano. He appears as a typical example of what Gail Hershatter called a "nesting subaltern", a person with shifting ties to those speaking "from above" and "from below". Depending on the situation, "nesting subalterns" can associate themselves with one group or the other. ${ }^{76}$

\section{Conclusions}

Despite his active borrowing of conceptual apparatus, as well as discursive and other practices, from Russian imperial contexts, Zhamtsarano was not a passive consumer of these discourses and practices. He reinvented the borrowed conceptual frameworks putting them to his own use and combining them with dominant discourses of the Mongolian Buddhist elites. Significantly, he ensured that his interpretations had a major impact in the Russian imperial center. Thereby, he played a crucial role in shaping how Buryats and the Mongolian people began to be seen by the imperial and early Soviet elites. Zhamtsarano's

74 Bazarov/Zhabaeva 2008: 307-309.

75 Compare Bayly 1996 and Cooper 2005: 24-32.

76 Hershatter 1993: 110-111. See also Lazzerini 1997. 
impact was only enhanced by the hybrid nature of his imaginings and interpretations, as in the first decades of the twentieth century influential imperial Russian experts on Buddhism came to the conclusion that developing a better understanding of that religion required an interpretative input of practicing Buddhists. Zhamtsarano's particular advantage was thus his belonging to several intersecting networks in an "imperial situation" which permitted a dominant hierarchy between the "European" center and the "Asian" periphery to be temporarily challenged.

Comparing the dates of Zhamtsarano's letters to imperial scholars and his articles in the press and of these scholars' own writings we can see that the depictions of Transbaikal Buryats as "the vanguard group” among the Mongols, of Buddhism as the Buryats' "national religion" and of the clan system as "a moral foundation" of the Buryat way of life were originally articulated by Zhamtsarano on the eve of and during the 1905 revolution, subsequently influencing imperial scholars and early Soviet policies. If in 1882 the expert on Siberia's inorodtsy and Siberian regionalist, Nikolai Yadrintsev, concluded that Russian settlers in Siberia were corrupted by the negative influence of "backward" and "racially inferior inorodtsy", starting from 1903, Zhamtsarano was consistently arguing the opposite. ${ }^{77}$ By the 1910s, Zhamtsarano's interpretation started to be accepted by the liberals among the imperial elites and then became part of the Bolsheviks' anti-settler narrative in the aftermath of the 1917 revolution. $^{78}$

We can see that Zhamtsarano's position as a subject of the Russian empire could oppress him, yet also empower him, particularly vis-à-vis some of his fellow Buryats and during his time in Outer Mongolia, where he was perceived by local officials as a colonizer, who was representing Russian and Soviet imperialism. His was not a parochial lifeworld; instead Zhamtsarano became a transnational and transcultural subject. But his vision of the Buryats as a distinct ethnocultural community with a right to national autonomy, yet also with a civilizing mission to perform among the Mongolian people and to act as a bridge between Europe and Asia and between Buddhism and communism was ambitious to the extent of becoming utopian.

Such transnational and transcultural subjects as Zhamtsarano, who were formed through the experiences of public activism of the last decades of the imperial regime and of the 1920s, became prime victims of Soviet repression in the 1930s, when the isolationism of the Soviet system was gaining momentum and the utopian impulses of the early twentieth century and the revolution

77 Yadrintsev 1882: 31.

78 Tolz 2011: 129, 130, 137. 
started to be perceived as a threat to the consolidating Stalinist regime. Zhamtsarano's fate thus highlights the extent to which the Stalinist model of the "imperial situation", while rhetorically underpinned by a strong condemnation of European colonialism and the celebration of the Soviet Union's ethnic diversity, hardened various internal and external boundaries, drastically reducing opportunities for their transgression.

Acknowledgment: I would like to thank Svetlana Gorshenina and the anonymous reviewers of the Asiatische Studien for providing useful comments and suggestions. Karénina Kollmar-Paulenz generously shared with me her knowledge of Zhamtsarano's writings in Mongolian. Her help with this issue proved invaluable.

\section{Bibliography}

Andreev, A.I. (2004): Khram Buddy v severnoi stolitse. St. Petersburg: Nartang.

Atwood, Christopher (2004): Encyclopedia of Mongolia and the Mongol Empire. New York: Facts on File.

Aust, Matin et al. (eds.) (2010): Imperium inter pares: Rol transferov $v$ istorii Rossiiskoi imperii (1700-1917). Moscow: Novoe literaturnoe obozrenie.

Barkey, Karen / von Hagen, Mark (eds.) (1997): After Empire. Multiethnic Societies and Nation-Building. The Soviet Union and the Russian, Ottoman and Habsburg Empires. Boulder, CO: Westview Press.

Bayly, Christopher (1996): Empire and Information. Intelligence Gathering and Social Communication in India, 1780-1870. Cambridge: Cambridge University Press.

Bazarov, B.V. (ed.) (2008): Buryatskie nationalnye demokraty i obshchestvenno-politicheskaya mysl mongolskikh narodov $v$ XX v. Ulan-Ede: FGOU VPO VSGAKI.

Bazarov, B.V. / Zhabaeva, L.B. (2008): Buryatskie nationalnye demokraty $i$ obshchestvenno-politicieshakaya mysl mongolskikh narodov v pervoi treti XX veka. Ulan-Ude: Izdat-vo Buryatskogo nauchongo tsentra SO RAN.

Bobrovnikov, V. (2010): "Russkii Kavkaz i frantsuzskii Alzhir: sluchainoe skhodstvo ili obmen opytom kolonialnogo stroitelstva?”. In: Imperium inter pares: Rol transferov $v$ istorii Rossiiskoi imperii (1700-1917). Edited by Matin Aust et al. Moscow: Novoe literaturnoe obozrenie, 182-209.

Bogdanov, Mikhail (1907): “Buryatskoe 'vozrozhdenie””. Sibirskie voprosy 3: 38-49.

Burbank, Jane / Cooper, Frederick (2010): Empires in World History: Power and the Politics of Difference. Princeton, NJ: Princeton University Press.

Cooper, Frederick (2005): Colonialism in Question. Theory, Knowledge, History. Berkeley, CA: University of California Press.

Cooper, Frederick / Stoler, Ann Laura (eds.) (1997): Tensions of Empire Colonial Cultures in a Bourgeois World. Berkeley, CA: University of California Press. 
Dugarova-Montgomery, E.-Kh. (2008): “Pismo Agvana Dorzhieva”. In: Buryatskie nationalnye demokraty i obshchestvenno-politicheskaya mysl mongolskikh narodov $v X X v$. Edited by B. V. Bazarov. Ulan-Ude: FGOU VPO VSGAKI, 261-269.

Espagne, Michel / Gorshenina, Svetlana / Grenet, Frantz / Mustafayev, Shahin / Rapin, Claude (eds.) (2015): Transfers culturels en Asie centrale: avant, pendant et après la Route de la Soie. Paris: Vendémaire.

Gerasimov, Ilya et al. (2005): "In Search of a New Imperial History”. Ab Imperio 1: 33-56.

Gerasimova, K.M. (1964): Obnovlencheskoe dvizhenie buryatskogo lamaistskogo dukhovenstva (1917-1930). Ulan-Ude: Buryatskoe knizhnoe izdatelstvo.

Glebov, Sergey et al. (2013): "The Postimperial Meets the Postcolonial: Russian Historical Experience and the Postcolonial Moment". Ab Imperio 2: 97-135.

Haenisch, Erich (ed.) (1955): Eine Urga-Handschrift des mongolischen Geschichtswerks von Sečen Sayang (alias Sanang Sečen). Berlin: Akademie-Verlag.

Hershatter, Gail (1993): “The Subaltern Talks Back: Reflections on Subaltern Theory and Chinese History”. Positions: East Asia Cultures Critique 1. 1: 103-130.

Hroch, Miroslav (1996): "From National Movement to the Fully-Formed Nation: The NationBuilding Process in Europe”. In: Becoming National: A Reader. Edited by Geoff Eley and Ronald Suny. New York: Oxford University Press, 60-77.

Kallinikov, A. (1928): “U istokov mongolskoi revolyutsii”. Khozyastvo Mongolii 3.10: 65-68.

Khalid, Adeeb (1998): The Politics of Muslim Cultural Reform: Jadidism in Central Asia. Berkeley, CA: University of California Press.

Khalid, Adeeb (1997): “Representations of Russia in Central Asian Jadid Discourse”. In: Russia's Orient. Imperial Borderlands and Peoples, 1700-1917. Edited by Daniel R. Bower /

Edward J. Lazzerini. Bloomington, IN: Indiana University Press, 188-202.

Khodorkovskii, Mikhail (1992): Where Two Worlds Met: the Russian State and the Kalmyk Nomads, 1600-1771. Ithaca, NY: Cornell University Press.

Khodorkovskii, Mikhail (2011): Bitter Choices: Loyalty and Betrayal in the Russian Conquest of the North Caucasus. Ithaca, NY: Cornell University Press.

Klements, D.A. (1907a): "Pessimizm na buryatskoi pochve". Sibirskie voprosy 10: 7-23.

Klements, D.A. (1908): "Zametki o kochevom byte”. Sibirskie voprosy, 49-52: 7-57.

Kollmar-Paulenz, Karénina (2014): "Systematically Ordering the World: the Encounter of Buriyad-Mongolian and Russian Knowledge Cultures in the 19th Century". In: Special issue of Etudes de Lettres. L'orientalisme des marges: éclairages à partir de l'Inde et de la Russie. Edited by Svetlana Gorshenina Philippe. Université de Lausanne, 2.3: 123-146.

Korostowetz, Iwan J. (1926): Von Chinggis Khan zur Sowjetrepublik. Berlin: de Gruyter.

Kozmin, N.N. (1923): “Tuzemnaia intelligentsiia Sibiri”. Sibirskaia zhivaia starina 1: 72-89.

Lazzerini, Edward J (1997): "Local Accommodation and Resistance to Colonialism in Nineteenth Century Crimea”. In: Russia's Orient. Imperial Borderlands and Peoples, 1700-1917. Edited by Daniel R. Bower and Edward J. Lazzerini. Bloomington, IN: Indiana University Press, 169-187.

Lieven, Dominic (2000): Empire. The Russian Empire and Its Rivals. London: John Murray. Marchand, Suzanne (2009): German Orientalism in the Age of Empire: Religion, Race, and Scholarship. Cambridge: Cambridge University Press.

Montgomery, Robert W. (2005): Late Tsarist and Early Soviet Nationality and Cultural Policy: The Buriats and Their Language. Lampeter: Edwin Mellen.

Pavlinskaya, L.R. (2008): Buryaty. Ocherki etnicheskoi istorii. St. Petersburg: Evraziiskii dom. Reshetov, A.M. (1998): “Nauka i politika v sudbe Ts. Zh. Zhamtsarano”. Orient, 2-3: 5-55. 
Rozenberg, O.0. (1918): Vvedenie v izuchenie buddizma (po yaponskim i kitaiskim istochnikam), part. 2: Problemy buddiiskoi filosofii. Petrograd: Izdaniya fakulteta vostochnykh yazykov Petrogradskogo universiteta.

Rupen, Robert A. (1956): “The Buriat Intelligentsia”. The Far Eastern Quarterly 15. 3: 383-398. Sharf, Robert H. (1993): “The Zen of Japanese Nationalism”. History of Religion 33.1: 1-43.

Shternberg, L.Ya. (1910): "Buryaty”. In: Formy natsionalnogo dvizheniya $v$ sovremennykh gosudarstvakh. Edited by A. Kastelyanskii. St. Petersrburg: Obshchestvennaya polza, 604-624.

Tolz, v. (2013): “Sobstvennyi Vostok Rossii". Politika identichnosti i vostokovedenie v pozdneimperskii i rannesovetskii period. Moscow: Novoe literaturnoe obozrenie.

Tolz, Vera (2011): "Russia's Own Orient”. The Politics of Identity and Oriental Studies in the Late Imperial and Early Soviet Periods. Oxford: Oxford University Press.

Tolz, V. (2010): "Rossiiskie vostokovedy i obshcheevropeiskie tendentsii v razmyshleniyakh ob imperiyakh kontsa XIX - nachala XX veka”. In: Imperium inter pares: Rol transferov $v$ istorii Rossiiskoi imperii (1700-1917). Edited by Martin Aust et al. Moscow: Novoe literaturnoe obozrenie, 266-307.

Tolz, Vera (2009): “Imperial Scholars and Minority Nationalisms in Late Tsarist and Early Soviet Russia”. Kritika: Explorations in Russian and Eurasian History 10.2: 261-290.

Tsybikov, B. (2003): Buryatskie uchenye national-demokraty. Ulan-Ude: Izdatelstvo BNTs SO RAN.

Tsybikov, B. / Chimitdorzhiev, Sh. (1997): Tsyben Zhamtsarano. Ulan-Ude: Biografii vydayushchikhsya deyatelei Buryatii.

Weisberger, Adam (1992): “Marginality and Its Directions”. Sociological Forum 7.3: 425-446.

Werth, Paul W. (2000): "The Limits of Religious Ascription: Baptized Tatars and the Revision of 'Apostasy', 1840s-1905”. The Russian Review 59.4: 493-511.

Yadrintsev, N.M. (1882): Sibir kak koloniya. St. Petersburg: Tipografiya M. M. Stasyulevicha.

Zhamtsarano, Ts. (2011): Putevye dnevniki, 1903-1907 gg. Ulan Ude: Respublikanskaya tipografiya.

Zhamtsarano, Ts. (1936): Mongolskie letopisi XVII veka. Moscow-Leningrad: Izdatelstvo Akademii Nauk SSSR.

Zhamtsarano, Ts. (1909): “Ongony aginskikh buryat”. Zapiski Imperatorskogo Rossiiskogo Geograficheskogo Obshchestva, 34: 393-397.

Zhamtsarano, Ts. (1907): “Buryaty i osvoboditelnoe dvizhenie”. Sibirskie voprosy 7: 3-10.

Zhamtsarano, Ts. (1906): “O pravosoznaii buryat”. Sibirskie voprosy 2: 167-184.

Note: An earlier, shorter version of this article is forthcoming in Espagne et al. (2015) under the title "Réconcilier le nationalisme ethnique et le cosmopolitisme impérial: les visions nationalistes de Cyben Žamcarano (1880-1942)". 